1st International Conference - Global Ethics - Key of
Sustainability (GEKoS) | May 15th, 2020 | Bucharest, Romania

\title{
Ethics in the Proliferation of Military Industry
}

Denisa-Atena COSTOVICI (MEMA)

https://doi.org/10.18662/lumproc/gekos2020/30

How to cite: Costovici (Mema), D.-A. (2020). Ethics in the Proliferation of Military Industry. In A. Grigorescu \& V. Radu (vol. ed.), Lumen Proceedings: Vol. 11. 1st International Conference Global Ethics - Key of Sustainability (GEKoS) (pp. 295-304). Iasi, Romania: LUMEN Publishing House. https://doi.org/10.18662/lumproc/gekos2020/30 


\title{
Ethics in the Proliferation of Military Industry
}

\author{
Denisa-Atena COSTOVICI (MEMA) ${ }^{1}$
}

\begin{abstract}
The 21st century, ethics has become a much challenged concept. As globalization has turned the world into a connected trade platform, international business flourished. Like many industries, arm trading has evolved and is subject to major changes both qualitative and quantitative. How important are revenues in comparison to fueling regional conflicts? Ethics has become an important criterion through which we should regard arms trading as well. States are engaged in a rearing arms race labeling it as peacekeeping and thus generating instability and tensions. At which point commercial activities and political interests converge and to what extent ethic considerations are respected? The objective of the article is to outline the new architectural perspective of security and defense. Attempting to avoid future wars, the nations widen their power through the strengthening of the military forces. The increasing defense budget, the development of the military capabilities and the expenditures - weapons industry's spending in the last decade contradict the states' allegations that they represent only proactive measures to face potential threats; for the defense walls must be built, not purchased cannons. The purpose of this paper is to bighlight the major changes regarding national defense in today's challenges. The cutting-edge technology developed in the name of resilience to the asymmetries in the theaters of operations (and not only) is transposed economically as larger acquisitions and budgets allocated for the security of nations. Moreover, in the military plan it consolidates the position of a state in the global polycentric reality, shifting the balance towards hard power.
\end{abstract}

Keywords: military development; ethics; army; proliferation; justification.

\footnotetext{
${ }^{1}$ Valahia University of Targoviste, Romania, E-mail: denisa21co@gmail.com

(c) The Authors, LUMEN Conference Center \& LUMEN Proceedings.

Selection and peer-review under responsibility of the Organizing Committee of the conference
} 


\section{Introduction}

Ethics has its beginnings in the 21 st century $\mathrm{BC}$, a set of rules being mentioned in Hammurabi's code, carved in a 2.25 meter long diorite stele, most likely around $1760 \mathrm{BC}$. The researchers found that other leaders (the Sumerian king Ur-Nammu, 2112 BC - 2095 BC and the king of Isin, LipitIshtar, 1934 BC - 1924 BC) ordered the inscription of similar codes. According to the Romanian Explanatory Dictionary, ethics is the science that deals with the theoretical study of human values and condition, from the perspective of moral principles and their role in social life. Therefore, ethics is the science that inextricably links morality with human and social existence.

The role of ethics is to calibrate decisions in everyday life. It is ubiquitous in all fields of activity: in psychology, research, business, intelligence, social work, etc. Business ethics is defined by the National Agency for the Security of Information Systems as a discipline on the border between the philosophy of morality and management, so it is not just about resolving or preventing conflicts [1].

This involves establishing a trade-off between the interests of the parties directly involved and the interests of the groups affected or indirectly affected, from partners to consumers, with different repercussions on society as a whole [16]. Due to its importance, an attempt was made to outline a behavioral conduct of business ethics. Thus, there are many codes of ethics and conduct in business, even strict regulations. For example, conflicts of interests, incompatibility, malfeasance etc. are regulated at EU level by the Recommandation No. R (2000) 10 of the Committee of Ministers to Member states on codes of conduct for public officials, which has been taken over and transposed by the Member States.

\section{Problem Statement}

The analysis of the evolution and particularities of the international system after the Cold War concludes that the end of the century marked the drawing of new strategic and economic lines and an unprecedented institutional dynamics [7]. The end of the balance of power characterized by the tensions between the USA and the Soviet Union gave rise to a process with a blurred, dynamic contour, passing "from a unipolar architecture characterized by US supremacy, to a multilateral or multipolar one by the existence of several power poles, leading to a strongly globalized one, that includes new networks characterized by new forms of interaction, diffusion of power, multiple non-governmental actors, complex interdependence and new global challenges [17]". 
Frozen conflicts, the aftermath of the Cold War, terrorist attacks, cybercrimes, the development of competition, protection and resilience are just some of the military dilemma that have highlighted the growing importance of national security and defense [22].

The proliferation of military capabilities and their easy access have been predicted since the middle of the twentieth century. Historian Carroll Quigley [18] said that the hope for the future would not lie in the occupying of more states by a superpower, but that new weapons and war tactics would be invented, which would be relatively easy to obtain and use, and would increase the effectiveness of the guerrilla war. This context has favored the emergence of combined and interconnected ethical concerns about the spread of moral responsibility and the loss of human dignity.

\section{Aims of the research}

We have chosen to analyze a sub-domain of business ethics, which is very controversial nowadays. Ethics in the weapons business involves a particular situation, which is often not analyzed as being multy-layered. Business ethics is most often analyzed from a competitive perspective, with conflicts of interest or the subjective way in which it manifests itself, but very rarely do researchers start with a basic question: Is the main object of business ethical in its nature?

In the analyzed case, is the need for the proliferation of military capabilities well-founded? Under the umbrella of defense, states are acquiring increasingly accurate annihilation devices. In this context, we consider relevant this question: Is premeditated killing allowed? And if so, who regulates it? In response to the chosen strategy, respectively the behavioral ethics in the massive acquisitions of weapons, the military leaders state that they often face moral dilemma, but that their own tactics are influenced by those chosen by their enemies [20]. However, where is the threshold between defense and offensive? Is the death of someone a fair price for security? Who gives the license to kill - an authority, a state leader, an international organization? Moreover, where is the place of ethics in ordering or ignoring the death of a person?

The purpose of the study is to underline some of the instruments and methods chosen by the states to maintain the national security or the offensive against their enemies, means which are on the verge of breaking the principles of ethics. The latest worldwide cases of ethical dilemma are presented in order to validate the allegations.

The scientific paper has two basic hypotheses. The first focuses on the proliferation and use of military devices and techniques whose outcome 
frequently affects innocent people. The second research hypothesis analyzes whether the involvement of collateral victims, even before the shooting order is given, and the assumption of these damages by decision makers is unethical.

\section{Research Methods}

The methodology used in the research study involves the thematic analysis of the proliferation of weapons and the efficiency of annihilation tools without respecting ethical criteria.

The presented data was collected through the empirical study and then processed in order to validate or invalidate the working hypothesis.

The method of empirical theory will be used to study the actions and interactions between the phenomenon of proliferation and development of military armaments and the multiplication of collateral victims of state conflicts. Using the instrument of case study, a series of events will be analyzed as a result of the evolution of devices used on the battlefield. The study finds its utility by emphasizing less debated aspects but with strategic value, namely the inaccuracy of weapons in achieving the expected result.

\section{Findings}

In a world where states are failing to provide medical services and education to all citizens, the weapon development industry is constantly flourishing. Industry developers say they face ethical dilemma when it comes to upgrading weapons by augmenting the capabilities of the users to cause direct physical harm to people or structures [9]. Given the regulations of the criminal codes prohibiting murder, as well as the internationally recognized fundamental right to life, how will the weapon development industry explain its ongoing research?

The explanation lies in a utilitarian perspective, the continued maintenance of a strong military force but which can endanger the lives of many citizens [3]. The motivation replaces ethical principles and human rights and facilitates the ongoing development of mass annihilation technologies.

Examples of complex and effective contemporary annihilation systems [11] include: (Anti-personnel) landmines, armed drones [13], surgical strike [19] attacks, weapons of mass destruction (WMD). The research will analyze the evolution, spread and proliferation of these types of weapons / destruction systems from the perspective of ethics.

- The proliferation of landmines is based on an unethical purpose. In recent decades, mines have been used as weapons to increase terror against 
the local civilian population, in an attempt to isolate or force them to accept certain decisions by depriving them of access to agricultural land, important roadways, and even vital necessities such as access to drinking water or firewood. The landmine system involves injuring or killing any being who comes in contact with them, whether we are talking about combatants or civilians, animals or children. Unfortunately, their effects are long lasting and can explode even decades after installation.

Currently, 11 countries are identified to have the capacity to produce landmines: China, Cuba, India, Iran, Myanmar, North Korea, Pakistan, Russia, Singapore, South Korea and Vietnam. The states leaders affirm they do not operate in this area, but experts contradict the allegations. In addition to these military powers, insurgents are producing mines in underdeveloped countries such as Afghanistan, Nigeria and Yemen.

Also, from the perspective of ethics, we will analyze the costs of disabling them. We reiterate the idea that landmines do not know the difference between peace or war and once installed they must be properly defused otherwise, there is a risk of exploding at any time and on anyone. We will focus the discussion on the costs of a landmine defusing, which is done individually and amounts to $\$ 300-1000$ per mine. Even experts with training in mine clearance know that for every 5,000 defused mines a specialist is killed and two workers are injured by accidental explosions [8]. In 2018, the number of known victims reached 6897 [12] people; of which $71 \%$ are known to be civilians and the percentage may actually be higher.

In this context, people could wonder why minefields are produced annually? The answer lies in creating annihilation systems with relatively low production costs (between $\$ 3$ and $\$ 75$ ) which modern technology allows. This is how small land mines are created, made of plastic, with a colorful and ultramodern design that can camouflage their appearance. Unfortunately, these features make them even more attractive to children, who could confuse them with toys.

The Ottawa Treaty (18th September 1997) also known as the Mine Ban Treaty promoted The Convention on the Prohibition of the Use, Stockpiling, Production and Transfer of Anti-Personnel Mines and on Their Destruction. Despite the fact that in May 2019 more than 150 states were party to the Convention, the world's major powers in terms of military resources (US, Russia, China, India, Pakistan) did not sign the act. The latest actions taken by the main international actors, which are constantly developing minefield systems, are contradicting the principles of this Convention. Under the dome of improving the functionality of the mines, respectively to reduce (or stop, as the states imply) affecting civilians with explosives, they are working on the development of smart land mines. Thus, 
the US invested over 100 million into the Gator Landmine Replacement Program, and Russia continued its ambitious project - the Medalyon POM-3 system at the end of 2015, consisting of an electronic nano brain and described by engineers as being "impossible to crack" [15].

Every year, landmines kill vulnerable categories: children, women and elders [23]. Landmines are also known to have been spread in about 78 countries, being memories of their armed conflicts. Quantifying the deaths, following the implementation and use of these annihilation systems, we can conclude that landmines are random carnage systems. However, international actors continue to produce and use them as war weapons [4].

- Drones appeared in the late 1990s and are now used for a wide range of activities such as recreation, filming, state border monitoring, transporting medicines to sensitive areas, etc [14]. The position of drones in the military began with the Kosovo War (1999) and the proliferation of armed drones was developed immediately after the 9/11 attacks and was linked to the so-called "war against terror".

The debate on the ethical nature of using these means of warfare is out of the question when their results are as expected and security objectives are achieved [2]. However, we cannot ignore the fact that there are failures and these consist in the loss of lives of innocent people. In general, these errors are not highly publicized. The discussion about target killing drones can be even more controversial [21]. Target killing has always been present in history. What may be new is the entry of this concept into legality and the use of drones as a tool in achieving the goal. We will not go into details about their inclusion in the security policy of the states, but we will mention some historical episodes in which drones fail to hit the target. On August 4, 2018, an attack was launched against the President of Venezuela, Nicolas Maduro, using armed drones with explosives. They missed the target but seven soldiers were wounded. Another example of the operation error of the drone annihilation system is that of Khogyani district of Nangarhar province, Afghanistan on September 19, 2019. The incident occurred because of the misidentification of persons, when the US intended to attack a hideout of some ISIS leaders (members of the Daesh terrorist group). Instead, the attack was launched near a pine seed crop, killing more than 30 workers and injuring 40 others, all civilians. The survivors of the massacre sent a message to the United States that such a mistake could never be justified and that a war is not won by killing civilians.

As we have stated, we will not analyze the right to target killing, but we will focus on the use of armed drones as annihilation systems. The frequency of using drones lies in the fact that they bring the means of combat at a relatively low cost. No one is publicizing the likelihood of 
mistakes, which often consist of killing civilians. At most, a medium- and long-term effect of accessing and using drones as weapons by all international actors, including emerging powers or terrorist groups, is taken into account. The advantage of the drones is that they can enable states to carry out targeted killings efficiently, at relatively low cost, and at minimal risk. In conclusion, we are not arguing the right of remote killing but ethics should be involved at least in evaluating the damages of the failures.

The leading hypothesis of this research paper also includes the use of weapons of mass destruction, such as biological, chemical, radiological or nuclear weapons, which pose serious risks and threats to world peace and the security of nations.

The most devastating bio-weapons were classified by the army as: Anthrax, Botulinum toxin, Small pox, Tularemia, Ebola Virus, Yersinia pestis, Marburg Virus, Bunyavirus, Aflatoxin. The latest debates of the moment focus on the controversy of integrating the new coronavirus SARS$\mathrm{CoV}-2$ into this category.

Bio-weapons are known to be used mainly by terrorist organizations. From the mentioned category, we will focus our attention on a constant and recently used example - anthrax. This infectious disease is caused by the bacterium Bacillus anthracis and can be transmitted through the skin or respiratory tract.

Over time, the disease has claimed lives among humans and animals. Since 1980, research has been carried out on this microorganism regarding its use as a biological weapon. Currently, 17 countries are suspected of having such an arsenal.

In the last 2 decades, several letters containing anthrax have been reported: on October 5, 2001, in Florida, USA, following the inhalation of the anthrax-causing bacillus, the editor of a tabloid died; On October 20, 2001, three letters containing anthrax spores were sent to Washington DC, USA, addressed to members of the Senate, NBC News and The New York Post. The same method was used on November 2, 2001 in Karachi, Pakistan, when a letter containing anthrax spores was sent to the Daily Jang.

The concept of chemical weapons encompasses substances that have the effect of killing a person or damaging vital organs, causing the victim to be unable to react properly. There are recent data confirming the use of chemical weapons of mass destruction by jihadist organizations, including the publication of a manual for the production of a mechanism for the dispersal of cyanic acid on Al-Qaeda sites, dating back to 2005. The terrorist group provides information on easily available chemical solutions: sodium cyanide (solution used as a poison for rats and cleaning of metal products) and hydrogen. The mixture of the two substances results in a colorless 
liquid, very volatile and stable in reaction with water. Inhaled as a gas, it is lethal. The mechanism is often used as it can be operated remotely. Osama bin Laden has made public Al-Qaeda's intention to procure weapons of mass destruction, with chemicals being the easiest to obtain and use [5].

Another chemical substance usually owned by armies around the world and used legally in combat - as a smoke bomb during daytime and as an incendiary bomb during night attacks - is white phosphorus [10]. The use of this chemical against civilians is illegal because it causes severe burns in contact with the skin. The Organization for the Prohibition of Chemical Weapons is investigating the launch by Turkey of such bombs in October, 2019 in the attack on the Syrian city of Ras al-Ayn. Several civilians, including children, suffered severe burns from chemicals substance released into the air by the Turkish army in the offensive against Syria.

Although the use of chemical weapons is intolerable and constitutes a violation of international law as its purpose may end in war crimes or crimes against humanity, we are still witnessing such attacks. The Syrian Arab Republic, the Islamic State in Iraq and the Levant (ISIL) [6] and Russia are the entities that have been the most publicized in this field. A recent example is the Syrian regime. Although the authorities have denied the (repeated) use of the national chemical weapons program, the distribution of sarin gas by the Syrian Arab Republic to Khan Shaykhoun (Syria) on April 4, 2018, proves otherwise.

\section{Conclusions}

The 21 st century has changed the strategies and lines of action drawn by the previous one (marked by 3 conflicts on a global scale) and brought to light new concepts of power, such as asymmetry, diffusion, transition, unpredictability and contextuality. What led to changes in the characteristics of power are the phenomena that appeared after the Cold War: globalization, the information revolution (Internet), interdependence.

These have shifted the way resources are evaluated and taken into account in the exercise of power in the international system. Carl von Clausewitz said "Every age has its own kind of war, its own limiting conditions, and its own peculiar preconceptions." Hybrid wars, characteristic to this century, tear states apart, pressuring them to adopt decisions that surpass the boundaries imposed by ethics.

The decisions and the actions undertook are justified by the need of the states to be resilient to asymmetric threats.

What we wanted to emphasize was the way in which military power is exercised and reflected, often violating ethical criteria. Deviations from 
codes of ethics are frequent and last but not least, flagrant. The research hypotheses were validated by the multiple cases presented, the data collected being analyzed as a sample applied to the global case studies in the field. The foundation of ethics applied militates for the harmonization of the principles of humanity with the contemporary proliferation of military industry.

\section{References}

[1] Asociația Națională pentru Securitatea Sistemelor Informatice. Norme etice în afaceri şi aspecte legale privind incompatibilitățile, conflictul de interese şi abuzul în serviciu - cadrul național, european şi internațional; 2016. Available from: http://anssi.ro/wp-content/uploads/2016/08/Etica-in-afaceri.pdf.

[2] Benmelech E, Frydman C. Military Ceos. Journal of Financial Economics; 2015 Jul 1;117(1): 43-59.

[3] Brehm M. Protecting Civilians from the Effects of Explosive Weapons. An Analysis of International Legal and Policy Standards, United Nations Institute for Disarmament Research, Geneva, Switzerland; 2012, pp. 31-86

[4] Byrne EF. The US military-industrial complex is circumstantially unethical. Journal of Business Ethics; 2010 1;95(2) :153-65.

[5] Centrul de Informare pentru Cultura de Securitate, Inamicul invizibil Bioterorismul şi armele biologice în lume, Bucureşti; 2016, pp. 6-11. Available from: https://www.sri.ro/upload/Brosura\%20Bioterorism.pdf

[6] Consiliul Uniunii Europene, Concluziile Consiliului privind dezarmarea şi neproliferarea în domeniul chimic în vederea celei de a patra sesiuni speciale a Conferinței statelor părți pentru examinarea funcționării Convenției privind interzicerea dezvoltării, producerii, stocării şi folosirii armelor chimice şi distrugerea acestora, Haga, 21-30 noiembrie 2018, Available from: http:/ / data.consilium.europa.eu/doc/document/ST-7862-2018-INIT/ro/pdf

[7] Grigorescu A, Costovici DA, Constantin M. Managing Asymmetric Conflicts in the Dynamics of the 21st Century. Strategica International Academic Conference - seventh edition, Bucharest, October 10-11, 2019. 75 p.

[8] Heinecken L. Outsourcing public security: The unforeseen consequences for the military profession. Armed Forces \& Society. 2014 Oct; 40 (4): 625-46.

[9] Held V. Can the ethics of care handle violence? Ethics and Social Welfare. 2010 Jul 1;4(2): 115-29.

[10] White Phosphorus (WP) Available from: https://www.globalsecurity.org/military/systems/munitions/wp.htm

[11] ICRC, Ethics and autonomous weapon systems: An ethical basis for human control? April 2018. Available from https://www.icrc.org/en/document/ethics-andautonomous-weapon-systems-ethical-basis-human-control

[12] International Campaign to Ban Landmines, Landmine Monitor 2019, Published on 21 November 2019, 21ST Annual Edition; 2019. Available from https://reliefweb.int/organization/icbl 
[13] Kenneth R. H. Drones and the Ethics of Targeted Killing, Paperback, Publisher: Rowman \& Littlefield, September 3; 2015.

[14] Luppicini R, So A. A technoethical review of commercial drone use in the context of governance, ethics, and privacy. Technology in Society. 2016 Aug 1;46:109-19.

[15] Michael B., Solène B.-N., Smart Mines: The Future Battlefield?, European Defence Researchers at Finabel - European Army Interoperability Centre, July, 30; 2019. Available from: https://finabel.org/smart-mines-the-futurebattlefield/

[16] Munteanu I, Grigorescu A, Condrea E, Pelinescu E. Convergent Insights for Sustainable Development and Ethical Cohesion: An Empirical Study on Corporate Governance in Romanian Public Entities. Sustainability. 2020 Jan; $12(7): 2990$.

[17] Puşcaş V. Intercultural communication in managing global interdependence, paper presented at the International Congress on Soft Power, Institute for International Studies, November, 2009, Berlin; pp. 1-5.

[18] Quigley C. The Evolution of Civilization: An Introduction to Historical Analysis, New York: Macmillan; 1961. 258 p.

[19] Shultz R.H., Pfaltzgraff R.L. The Future of Air Power: In the Aftermath of the Gulf War, Air University Press, Alabam, July 1992.

[20] Singer PW. The ethics of killer applications: Why is it so hard to talk about morality when it comes to new military technology?. Journal of Military Ethics. 2010 Dec 1; 9(4): 299-312.

[21] Stuart C-M. Pandora's box? Drone strikes under jus ad bellum,jus in bello, and international human rights. International Review of the Red Cross, June 2012 94 (886): 597 - 625, Published online: 23 April 2013. Available from: http://journals.cambridge.org/abstract_S1816383113000118

[22] The International Institute for Strategic Studies (IISS), The Military Balance 2020, 1st Edition, Publisher: Routledge, February 14, 2020

[23] United Nations, Demining, September, 3; 2017. Available from: https://web.archive.org/web/20170903114920/http:/www.un.org/en/sectio ns/issues-depth/demining/index.html 